日本建築学会技術報告集 第12号，245，2001年 1 月 AlJ J. Technol. Des. No. 12, 245, Jan., 2001

\title{
FM データベースとシミュレーションを用いた大学施設の利用計画立案と意思決定プロセス
} 一千葉大学工学部における施設再配分の計画事例を通じて一

岸本達也, 上野 武, 服部岑生

151

宮本文人 [東京工業大学文教施設研究開発センター 助教授・工博] 近年, 国立大学でキャンパス再開発の計画室が設置され，私立大 学を含め, 大学計画関係者により実務レベルで FM 適用への取組み が着実に行われている。

この論文は,この事実を裏付けるものであり, FM データべースを 基にシミュレーションを行い，実際の計画への適用について記述し ている点に意義がある。ただ，技術論文報告集の性格か，紙面の制 約のためか, FMの問題点やシミュレーションの方法について記述 が限定されている。今後，別の形で詳しく言及して頂ければ，今後 の発展に貢献するところが大きいと思われる。この論文における合 理性, 特に, 科学的合理性という言葉は, 様々な考え方が可能であ ク, 慎重に使用する必要があると感じた。大学計画において FM の取組みが有効であるかは歴史的な判断を仰がざるを得ないが，こ の種の研究が，再開発終了後も継続されることを願っている。
藤村達雄 [徳島大学施設部建築課 建築課長 $]$ 国立大学等施設は，2,321 万 $\mathrm{m}^{2}(\mathrm{H} 12.5 .1)$ ，全国の公・私立大学を 含めた保有面積の約 4 割と脰大なものを有している。これら施設の マネジメントには, 18 歳人口の減少, 財政基盤の悪化等, 大学がか かえる問題解決と, 大学改革の推進，科学技術創造立国の実現，社 会ニーズへの対応等を達成するために，施設品質の確保，施設の適 切な供給，施設財務の適正化を統括的に管理する経営手法である Facility Management（以下「FM」という。）の導入が必要である。

本稿に示された手法は, FM 導入の取組みとして高く評洒され, 施 設供給の適切で迅速な対応に資する画期的なもので，大学経営を司 る運営管理部署と教官の関係がフラットで緩やかである大学の構成 員教官一人一人に，現状と意志決定手順を示すことで自律的な判断 を促す有効な方法と思料される。なお, FM 導入に向けた今後の課題 は, 教育研究評価等に応じた施設供給手法, 施設品質・財務も含め た FMデータベースによる老朽改善シミュレーション等の確立で ある。
菊地成朋 [九州大学大学院人間環境学研究院都市・建築学部門 教授・工博 $]$

この報告は，自らが実践した施設づくりワークショップのプロセ スをレビューし，これをツールの提案につなげようとするものであ る。公共施設の設計に住民参加が広く取り入れられつつある現在, その方法論を確立しようとする試みは，社会状況からも機を得たも のといえる。住民参加のワークショップは，ややもするとファシリ テーターの個人的能力にその成否がゆだねられがちで，それが個人 に帰属しているままでは，真に社会的な効果は望めない。手法の普 及，一般化をめざす方向性は高く評価できる。

ただそうだとすれば，この報告の意義は，提案された手法が読者 に共有しうるものとして伝わるかどうかにかかっているといえる。 そのための情報が充分には提供されていないと感じた。その意味で は,限られた紙数を意義や経緯の説明にあてるよりも,ワークショッ プの実践的方法論にしぼって展開した方がよかったかもしれない。
林 泰義 [(侏計画技術研究所 代表取締役，千葉大学 客員教授 $]$ 参加のデザインには, 参加者の創造的提案を可能にし, 参加者と 設計者を橋渡しする方法が極めて重要な役割を果たす。パタンラン ゲージ,デザイン・ゲーム, $\mathrm{KJ}$ 法などはそれぞれにこのためのユニー クかつ有用な方法として，様々な現場で活用されている。

デザイン・ランゲージの方法は，伊藤雅春によって，参加の現場 の中からあみ出された。そして, 今日の日本でもっとも果敢に参加 のデザインに挑戦している伊藤と延藤安弘がこの方法を駆使した具 体例を紹介したのがこの論文である。

参加者と設計者が創造的な空間の実現のために，言葉を媒介にす ることが,この方法の核心をなしている。単に空間の形ではない生 活行動のイメージが語られることが, 生活の専門家である参加者と 空間の専門家である設計者を柔らかく結び，それぞれの自由な創造 力を発揮させる状況を生み出しているのである。
大野隆司 [東京工芸大学工学部建築学科 教授・工博] 段ボールの建材利用については，建具の心材など既に実績があり， また近年は，紙管による仮設住宅・建物が話題となった。こうした 状況を背景に，著者らのより標準化された建材・製品として段ボー ル積層パネルの開発意図は十分納得できるし, JIS のパネル試験法 を中心とした検討は極めて堅実なものと評価できる。

その上で（本報告はパネルの接合法がテーマであるが）積層パネ ルそのものについてあえて以下のような㗭念を指摘しておきたい。 1 現状では石高ボードなどとの複合は、リサイクル時に難しい問題 を生じる可能性が高いのではないか。

2 標準化の適正度合い（部品形）は仮設住宅の規模・形・部品分割 方法などにより異なるのではないか。
角田 誠 [東京都立大学大学院工学研究科建築学専攻 助教授・工博] 自然災害の被災者を受け入れる仮設住宅は, 被災者の精神的・物 理的ダメージを早急に軽減することが第一であり，本報告は仮設住 宅の構築法に対し新たな知見を示したものとして高く評洒できる。

確認された結果についていくつかの疑問を挙げたい。まず本仮設 住宅が再使用を想定しているかである。一度使用したものを分解・ ストックし新たな災害に対し用いることは，緊急対応性の点で有効 であるが，示された直交壁接合部，基礎・床接合部では対応が困難 と思われる。次に使用する段ボールの性質である。現状の段ボール は強度・耐水性・断熱性に優れたものが開発されているが，それら の使用は居住性能の向上に有効と考之られる。最後に基礎部の構法 である。特に地震災害では地盤面の状況が想定しづらいこと等を考 えると，全てを段ボール積層パネルで構成することに若干の疑問を 感じる。上述指摘の確認も含め，さらなる開発・検討を期待したい。 